\title{
PROTOTIPE PORTAL KOMPLEK PERUMAHAN DENGAN SISTEM RFID (Radio Frequency Identification) BERBASIS ARDUINO MEGA 2560
}

\author{
Ben Candra $S^{1)}$, Aris Sunawar ${ }^{2)}$, Nur Hanifah $\mathbf{Y}^{3)}$ \\ SI Pendidikan Teknik Elektro, Fakultas Teknik, Universitas Negeri Jakarta \\ Email: ben.chandra@ymail.com
}

\begin{abstract}
Issue in this paper is to explain about the making of "The Prototype of portal housing with RFID-based system arduino Mega 2560". Recently, many cases of theft and robbery in housing, especially in the elite residential State, which is due to a weak security system and there is no limit access to people in entering a residential State environment.In this thesis, the author intends to answer questions and provide solutions on the weakness of the security system and the restrictions in the access using RFID card that serves to open access doorstop contained in post enters into a residential state.

The method used in this paper is a method book study and discussion by collecting the information by finding references related to the research conducted. In this prototype Arduino Mega 2560 is a control device used for this prototype system, because the Arduino Mega 2560 has a number of inputs and outputs and having an Ethernet port to facilitate for the settings.

This prototype so is suitable implementation of her for use in residential complexes and commercial resident, as it helps in running the security system where every vehicle that does not have access cards (RFID Card) / registered in the database, cannot enter into a residential housing that implement this prototype.
\end{abstract}

Kay Word: RFID, Komplek Perumahan, Palang Otomatis, \& Arduino Mega 2560

\begin{abstract}
Abstrak
Pokok pembahasan dalam skripsi ini adalah menjelaskan tentang pembuatan "prototype portal komplek perumahan dengan sistem RFID berbasis arduino mega 2560". Belakangan ini banyak terjadi kasus pencurian dan perampokan pada perumahan, terutama di lingkungan kompleks perumahan elit, yang dikarenakan lemahnya system keamanan dan tidak ada batasan akses orang dalam memasuki sebuah lingkungan komplek perumahan.Pada skripsi ini penulis bermaksud untuk menjawab pertanyaan dan memberikan solusi tentang lemahnya system keamanan dan pembatasan orang dalam akses masuk dengan menggunakan kartu RFID yang berfungsi untuk akses membuka palang pintu yang terdapat di pos masuk dalam sebuah komplek perumahan. Metode yang digunakan penulis dalam penulisan skripsi ini adalah metode studi pustaka dan diskusi dengan melakukan pengumpulan informasi yang dilakukan dengan mencari referensi-referensi yang berhubungan dengan

penelitian yang dilakukan. Pada prototype ini Arduino Mega 2560 adalah perangkat kendali yang dipakai untuk system prototype ini, karena Arduino Mega 2560 memiliki jumlah input dan output yang banyak dan mempunyai port Ethernet sehingga memudah kan dalam pengaturannya.Prototipe ini sangat lah cocok implementasi nya untuk digunakan pada kompleks perumahan maupun niaga perkomplekan, karena membantu dalam menjalankan system keamanan dimana setiap kendaraan yang tidak mempunyai access card (RFID Card)/ terdaftar dalam database, tidak dapat masuk kedalam kompleks perumahan yang mengimplementasikan prototype ini.
\end{abstract}

Kata Kunci: RFID, Komplek Perumahan, Palang Otomatis, \& Arduino Mega 2560

\section{PENDAHULUAN}

Dalam perkembangan zaman diera globalisasi saat ini kemajuan teknologi sangat berkembang dan itu menunjukkan suatu efisiensi dalam penggunaanya. Kepraktisan teknologi dalam perkembangan tersebut sangat mempengaruhi kebutuhan manusia untuk membuat suatu alat yang berfungsi untuk membantu penghuni perumahan bagi yang tingkat kerjanya menuntut jam-jam malam, meningkatkan kenyamanan malam hari di perumahan, dan pertumbuhan industri real estate.

Pada saat ini, keamanan dalam berbagai wilayah sangat perlu ditingkatkan terutama pada wilayah komplek perumahan, di mana pengontrolan portalnya masih menggunakan 
sistem manual yaitu dengan tenaga manusia/satpam. Pengontrolan keamanan portal yang banyak dijumpai dengan menggerakkan portal tersebut untuk membuka dan menutupnya masih mengandalkan tenaga manusia tidak secara otomatis. Untuk itulah dikembangkan suatu alat yang dapat digunakan sebagai pengontrolan keamanan pada perumahan komplek.

Adanya sistem keamanan portal pada perumahan komplek maka penghuni komplek dapat mengendalikan portal tanpa harus menunggu satpam untuk membuka dan menutupnya karena portal merupakan jalur penghubung utama untuk masuk ke dalam komplek perumahan, sistem keamanan portal kali ini menggunakan sistem RFID (Radio Frequency Identification) dan juga kamera yang terhubung pada RFID untuk menangkap gambar kendaraan yang keluar masuk komplek perumahan.

Sensor yang menggunakan kartu khusus untuk penghuni perumahan.RFID merupakan teknologi identifikasi yang relatif fleksibel, mudah digunakan dan cocok untuk dipakai pada sistem yang berjalan secara otomatis. Jika terdapat penghuni perumahan yang kehilangan kartu khusus penghuni komplek, penghuni dapat menekan tombol bantuan yang sudah disediakan diportal tersebut, dan secara otomatis satpam akan menghampiri penghuni tersebut dikarenakan terdapat bel yang secara otomatis jika tombol bantuan ditekan, maka akan berbunyi.

Pada saat penghuni sudah berbicarakalau kartu khusus nya hilang, satpam akan meminta Kartu Tanda Pengenal (KTP) dan memverifikasi apakah penghuni tersebut sudah termasuk penghuni khusus atau tidak. Jika benar penghuni khusus perumahan tersebut satpam akan menekan tombol di aplikasi server untuk memerintahkan portal tersebut untuk membuka. Kalau dia bukan termasuk penghuni khusus perumahan/tamu, satpam akan bertanya untuk apa dia datang dan mencari siapa, jika benar tamu tersebut mencari kerabatnya satpam akan menghampiri kerabatnya dan memverifikasi apakah benar tamu tersebut adalah kerabatnya, karena tidak sembarangan orang dapat masuk, jika sudah benar kerabatnya satpam akan menekan server otomatis untuk memerintahkan agar portal terbuka.

Terdapat juga sensor proximity, jika penghuni khusus menempelkan kartu RFID, kemudian cocok akan ditandai lampu hijau yang artinya penghuni tersebut cocok/member khusus perumahan tersebut. Juga kamera akan mengambil gambar kendaraan, kemudian mengirim data ke komputer pusat, pada saat kendaraan sudah melewati portal, maka dengan sendirinya portal akan tertutup dengan sendirinya. Begitupun jika kendaraan tersebut keluar.

Penulis memilih membuat alat keamanan portal komplek perumahan ini agar membuat nyaman penghuni perumahan untuk menghindari tindakan kriminal pencurian kendaraan pada area komplek perumahan dan mempermudah akses keluar atau masuk perumahan bagi para penghuni komplek perumahan.

\section{Arduino Mega 2560}

Arduino merupakan kit elektronik open source yang dirancang khusus untuk memudahkan setiap orang dalam belajar membuat robot atau mengembangkan perangkat elektronik yang dapat berinteraksi dengan bermacam-macam sensor dan pengendali. Arduino dapat mengenali lingkungan sekitarnya melalui berbagai jenis sensor dan dapat mengendalikan lampu, motor, dan berbagai jenis aktuator lainnya.

\section{Palang Portal Perumahan}

Penerapan sistem portal komplek perumahan di masyarakat luas sudah banyak sekali kita jumpai. Sistem portal tersebut masih menggunakan metode konvesional, yaitu petugas keamanan harus memasukkan data kendaraan secara manual, baik pada sistem pencatatan tangan maupun komputer. Proses memasukkan data kendaraan secara manual sering kali membutuhkan waktu yang cukup lama, sehingga menyebabkan makan waktu akses yang cukup panjang. Beberapa penelitian untuk memperbaiki sistem konvesional ini sudah mulai dilakukan.

Beberapa penelitian yang dilakukan sampai saat ini belum dijumpai adanya alat portal yang dapat memasukkan data kendaraan secara 
otomatis saat ingin masuk area perumahan. Dengan memasukkan data secara otomatis dapat memperkecil waktu yang diperlukan untuk masuk dalam area perumahan maupun saat keluar. Dengan demikian timbulnya antrian kendaraan saat akan masuk komplek perumahan dapat diminimalisir.

Sebagai solusi untuk menyelesaikan masalah tersebut maka kini dikembangkan sistem portal dengan sistem RFID sebagai alat identifikasi untuk mengenali pengguna kendaraan yang masuk area perumahan. Seperti yang diketahui bahwa RFID digunakan untuk menyimpan atau menerima data menggunakan suatu piranti yang bernama RFID tag atau transponder yang biasanya dibuat dalam bentuk kartu, stiker, dan lain-lain.

Dalam penerapan sistem palang portal sistem RFID ini memerlukan komponen pendukung utama yaitu palang portal otomatis sebagai pintu gerbang masuk dan keluar perumahan. Dalam pemakaiannya dua komponen ini (RFID dan palang parkir otomatis) terintegrasi dalam satu sistem kontrol. RFID disini berfungsi sebagai reader ID card perumahanyang mengecek keabsahan pengguna kendaraan saat masuk dan keluar perumahan (nomor polisi kendaraaan, foto muka dan helm yang dipakai).

Sedangkan palang portal otomatis sebagai pintu penghalang yang hanya akan membuka jika data yang diidentifikasi RFID benar. Untuk mengatasi masalah portal perumahan, maka solusi menggunakan portal Selain memudahkan akses untuk masuk perumahan, portal tipe tekuk juga akan mengurangi momen yang dihasilkan saat portal bergerak naik maupun turun. Sehingga cocok untuk digunakan pada motor penggerak yang memiliki daya yang tidak terlalu besar, seperti motor DC power window yang digunakan dalam rancangan palang portal otomatis.

\section{Aplikasi}

Menurut Blanchette dan Summerfield QT adalah sebuah kerangka kerja yang biasanya digunakan untuk membangun GUI (Graphical User Interface) dari sebuah aplikasi. QT ditulis dengan bahasa pemrograman $\mathrm{C}++$, juga menggunakan bahasa program yang disebut Meta
Object Compiler untuk menangani penambahan fitur-fitur yang tidak bias ditangani oleh $\mathrm{C}++$.

\section{RFID}

RFID adalah proses identifikasi seseorang atau objek dengan menggunakan frekuensi transmisi radio. RFID menggunakan frekuensi radio untuk membaca informasi dari sebuah device kecil yang disebut Tag atau Transponder (Transmitter + Responder). Tag RFID akan mengenali diri sendiri ketika mendeteksi sinyal dari device yang kompatibel, yaitu pembaca RFID (RFID Reader). RFID adalah teknologi identifikasi yang fleksibel, mudah digunakan, dan sangat cocok untuk operasi otomatis. RFID mengkombinasikan keunggulan yang tidak tersedia pada teknologi identifikasi yang lain.

RFID dapat disediakan dalam device yang hanya dapat dibaca saja (Read Only) atau dapat dibaca dan ditulis (Read/Write), tidak memerlukan kontak langsung maupun jalur cahaya untuk dapat beroperasi, dapat berfungsi pada berbagai variasi kondisi lingkungan, dan menyediakan tingkat integritas data yang tinggi. Sebagai tambahan, karena teknologi ini sulit untuk dipalsukan, maka RFID dapat menyediakan tingkat keamanan yang tinggi. Pada sistem RFID umumnya, Tag atau Transponder ditempelkan pada suatu objek. Setiap Tag dapat membawa informasi yang unik, diantaranya: serial number, model, warna, tempat perakitan, dan data lain dari objek tersebut. Ketika tag ini melalui medan yang dihasilkan oleh pembaca RFID yang kompatibel, tag akan mentransmisikan informasi yang ada pada tag kepada pembaca RFID, sehingga proses identifikasi objek dapat dilakukan.

\section{Webcam}

Webcam adalah kamera digital yang dikoneksikan ke komputer, digunakan untuk telekonferensi video atau tujuan lain. Webcam dapat menangkap gambar video gerak-penuh, dan beberapa model termasuk mikrofon dan kemampuan zoom. 


\section{Motor Servo}

Motor servo standard (servo rotation $180^{\circ}$ ) adalah jenis yang paling umum dari motor servo, dimana putaran poros outputnya terbatas hanya $90^{\circ}$ kearah kanan dan $90^{\circ}$ kearah kiri. Dengan kata lain total putarannya hanya setengah lingkaran atau $180^{\circ}$.

\section{Proximity}

Sensor proximity berfungsi untuk mendeteksi ada atau tidaknya suatu objek. Jenis-jenis sensor proximity:

\section{Induktif Proximity}

Tipe proximity yang bekerja berdasarkan perubahan induktansi apabila ada objek metal/logam yang berada dalam cakupan wilayah kerja sensor. Tipe ini hanya dapat mendeteksi benda logam saja dengan jarak deteksi maksimum sebesar $6 \mathrm{~cm}$. Bahan dasar logam sangat mempengaruhi kemampuan pendeteksian sensor.

\section{Kapasitif Proximity}

Tipe proximity yang bekerja berdasarkan perubahan kapasitas objek yang berada pada cakupan daerah kerja sensor. Tipe ini dapat mendeteksi semua jenis benda dan memiliki jarak maksimum $2 \mathrm{~cm}$.

\section{METODE}

Penelitian ini dilakukan di Laboratorium Bengkel Mekanik Jurusan Teknik Elektro Fakultas Teknik Universitas Negeri Jakarta. Waktu penelitian dilaksanakan pada tahun ajaran 2015/2016.

\section{Flowchart}

Flowchart dibagi menjadi 2 yaitu,Flowchart verifikasi tag RFID, dan Flawchart Pendaftaran.

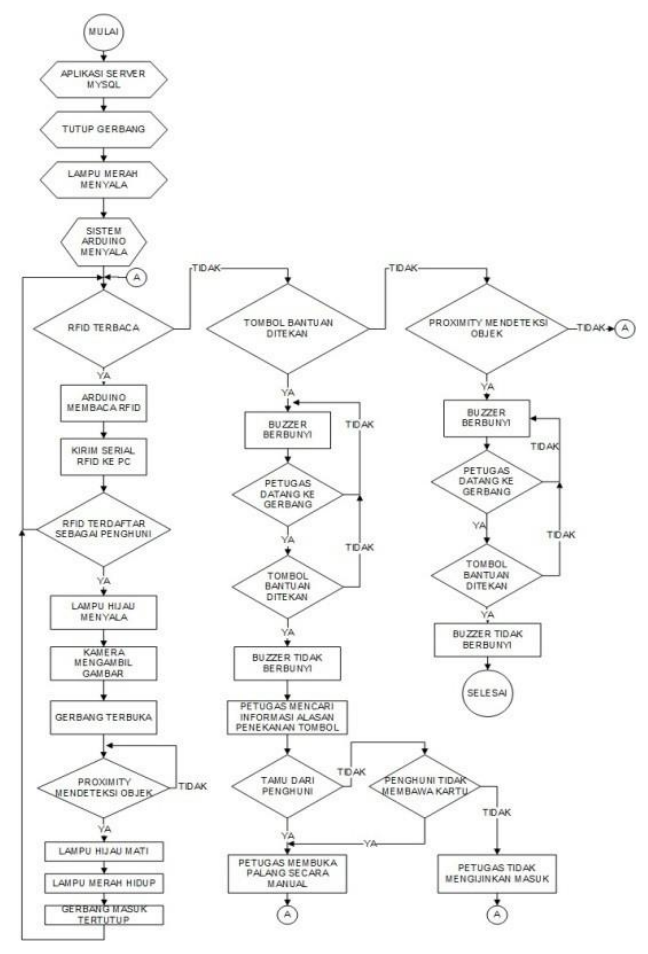

Gambar Flowchart verifikasi tag RFID

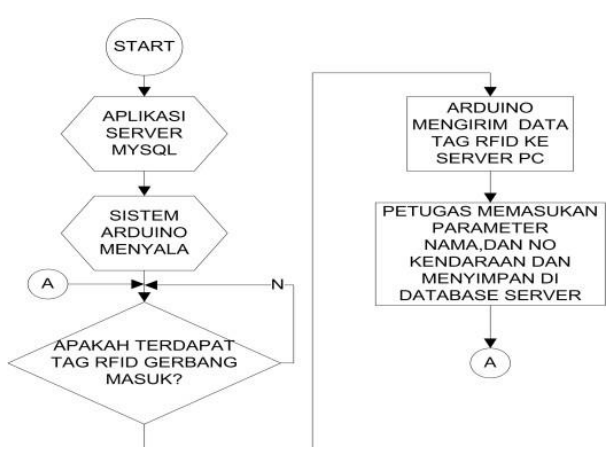

Gambar. Flowchart Pendaftaran

\section{HASIL DAN PEMBAHASAN}

Pada bab ini akan dilakukan pengujian dan analisa terhadap perangkat sesuai hasil perancangan dan implementasi. Perancangan perangkat diimplementasikan pada instalasi dan konfigurasi komponen. Setelah itu dilakukan pengujian untuk kemudian dilakukan analisa sehingga bisa memperbaiki perancangan sistem yang baru. Pengujian yang dilakukan yaitu pengujian secara fungsional 


\section{Analisis Data Penelitian. Pengujian Hardware}

Pengujian hardware pada sistem ini dilakukan untuk memastikan perangkat yang dirancang dapat berjalan sesuai dengan yang telah direncanakan :

1. Tombol Bantuan yang ditekan dapat terbaca oleh system yang akan memicu buzzer untuk berbunyi, tombol bantuan digunakan sebagai prosedur untuk memanggil bantuan ke operator aplikasi parkir.

2. Sensor yang dipasang pada gerbang masuk dan gerbang keluar dapat mendeteksi adanya objek.

3. Motor Servo dapat merespon hasil pembacaan/pendeteksian sensor yang kemudian bergerak secara otomatis untuk membuka dan menutup gerbang.

4. $L C D$ dapat menampilkan informasi untuk kendaraan yang akan masuk ataupun yang akan keluar.

5. RFID dapat terbaca ke Arduino sebagai identitas pengguna

6. Kamera dapat menampilkan gambar di aplikasi parkir

\section{Pengujian Catu Daya}

Rangkaian catu daya memberikan sumber tenaga yang akan digunakan oleh rangkaian-rangkaian yang dibuat pada prototipe ini karena merupakan sumber tenaga baik untuk mengaktifkan Sistem maupun rangkaian lain yang digunakan untuk menjalankan prototipe ini.

Pada sistem Penyiraman otomatis ini penulis menggunakan satu daya yang keluaran tegangannya sebesar $5 \mathrm{Vdc}$.

Berikut adalah langkah-langkah dalam mengukur catu daya :

1. Nyalakan avometer (digital), pilih skala "Vdc" pada avometer.

2. Hubungkan catu daya ke sumber tegangan AC.

3. Hubungkan jarum/probe merah (+) pada avometer ke inner connector pada catu daya \& hubungkan jarum/probe hitam (-) pada avometer ke outer connector pada catu daya.

4. Lihat pada display avometer, maka hasil pengukuran tegangan pun akan muncul.
Berikut adalah tabel hasil pengukuran catu daya $5 \mathrm{Vdc}$ :

\begin{tabular}{|c|c|c|}
\hline Keadaan & $\begin{array}{l}\text { Vout } \\
7805\end{array}$ & $\begin{array}{l}\text { Hasil } \\
\text { Pengujian }\end{array}$ \\
\hline On & $\mathrm{V}^{5.1}$ & Baik \\
\hline Off & $0 \mathrm{~V}$ & Baik \\
\hline
\end{tabular}

\section{Pengujian Tombol Bantuan dan Buzzer}

Pengujian ini dilakukan guna untuk mengetahui hasil dari perancangan dan percobaan sistem pada prototipe yakni tombol tombol bantuan yang dipasang pada pintu gerbang masuk yang berfungsi sebagai kendali untuk mebuat buzzer berbunyi.kriteria keberhasilan adalah buzzer berbunyi pada saat di lakukan penekanan tombol bantuan. Dan sebaliknya buzzer tidak berbunyi pada saat tombol tidak di tekan.

\section{Pengujian Led Indikator Masuk}

Pengujian ini dilakukan untuk mengetahui hasil tegangan yang dihasilkan oleh LED Indikator ketika kendaraan ingin masuk dan led indikator merah menyala yang berarti akses masuk belum diizinkan, dan ketika kendaraan sudah meng Tag kartu RFID maka LED indikator akan berubah menjadi hijau yang artinya kendaraan sudah diizinkan untuk masuk dan portal terbuka.

Hasil Pengujian LED Indikator.

\begin{tabular}{|l|c|c|}
\hline \multirow{2}{*}{ Kondisi } & \multicolumn{2}{|c|}{ Tegangan } \\
\cline { 2 - 3 } & $\begin{array}{c}\text { Led } \\
\text { Merah }\end{array}$ & $\begin{array}{c}\text { Led } \\
\text { Hijau }\end{array}$ \\
\hline Portal & 5 Volt & 0 \\
Tertutup & 0 & Volt \\
Portal & Volt & 3,1 \\
Terbuka & & Volt \\
\hline & & \\
\hline
\end{tabular}

\section{Pengujian Serial RFID}

Pengujian untuk komunikasi serial TTL dengan RFID dengan menggunakan software serial monitor yang bertujuan untuk mengetahui bagaimana rfid dapat dibaca melalui serial monitor dan jarak pembacaan rfid. Kriteria keberhasilan adalah terbacanya kode ascii melalui serial monitor.

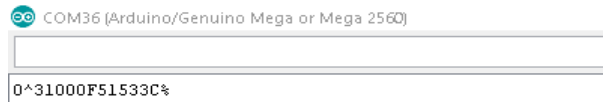


Gambar Pengujian Serial RFID

\begin{tabular}{|c|c|c|c|c|c|c|}
\hline No. & Kartu & Purtal Iu & Portal Out & Kode Ascii & Jarak & Hasil \\
\hline \multirow[t]{5}{*}{1} & 1 & $v$ & - & $31(1611+533151)$ & $16 \mathrm{M}$ & Scrvo $(2 n$ \\
\hline & 2 & v & - & 31000F 52315D & $2 \mathrm{CM}$ & Sezvo Ou \\
\hline & 3 & $\mathrm{v}$ & - & $31000 \mathrm{~F} 53315 \mathrm{D}$ & $3 \mathrm{MM}$ & Fervo on \\
\hline & 4 & 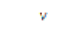 & - & 31000F52315D & $4 \mathrm{CM}$ & Servo Ou \\
\hline & 5 & $\mathrm{v}$ & & $31000 \mathrm{~F} 52315 \mathrm{C}$ & $5 \mathrm{CM}$ & Sarvo Off \\
\hline \multicolumn{7}{|c|}{ Tabel 1.1 hasil pembacain kertu ifld } \\
\hline No. & Kartu & Portal In & Portal Out & Kode $\boldsymbol{A s c l l}$ & Jarals & Hasll \\
\hline \multirow[t]{5}{*}{2} & 1 & & 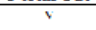 & $31000 \mathrm{~F} 52315 \mathrm{D}$ & $1 \mathrm{CM}$ & Servo Ou \\
\hline & 2 & & $\mathrm{~s}$ & 31000F52315D & $2 \mathrm{~cm}$ & Servo On \\
\hline & 3 & - & $\mathrm{v}$ & 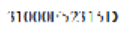 & แ:м & Servo ()n \\
\hline & 1 & & $\mathrm{v}$ & 31000F52315D & $1 \mathrm{CM}$ & Servo On \\
\hline & s & - & $\mathrm{v}$ & $31006153150:$ & $s \mathrm{CM}$ & Serwo (ntt \\
\hline
\end{tabular}

\section{Pengujian Kamera}

Pengujian Kamera dilakukan untuk mengetahui apakah kamera dapat melakukan pengambilan gambar dengan sempurna ketika ada objek yang mengenai sensor proximity.

\section{Pengujian Proximity}

Pengujian Proximity dengan meletakkan objek didekat sensor proximity sehingga dapat mengetahui jarak proximity dan tegangan yang dihasilkan oleh sensor proximity untuk men trigger kamera dan LED indikator masuk dan keluar pada palang pintu.

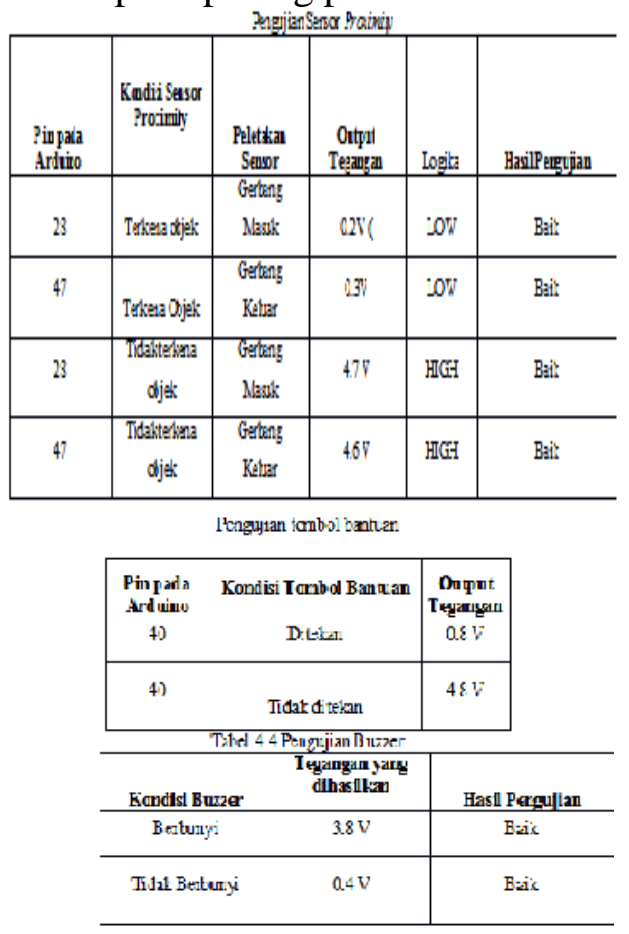

\section{KESIMPULAN}

Kesimpulan dalam penelitian ini adalah prototype portal komplek perumahan dengan sistem RFID berbasis arduino mega 2560 telah berfungsi dengan baik.

\section{SARAN}

Berdasarkan kesimpulan yang ditarik dari analisis data, maka penulis mencoba untuk memberikan rekomendasi dalam pengembangan prototipe ini pada sistem kamera yang dapat dijadikan juga sebagai cctv untuk memonitoring sekitar kompleks perumahan, serta sistem ini dapat mengenali plat nomer yang telah terbaca kamera dan tersimpan dalam database.

\section{DAFTAR PUSTAKA}

Ecadio. 2016 "Belajar dan mengenal arduino mega".https://books.google.co.id/books?id=D IQvCwAAQBAJ\&pg. Diakses Pada 22 Juli 2016.

Feri Djuandi. 2016. Pengenalan Arduino. Ebook. www.tobuku, Juli 2011 jilid 2. McLeod Jr. Diakses Pada 24 Juli 2016

McLeod Jr., Raymond, 2001, Sistem Informasi Manajemen, Edisi Ketujuh, PT Prenhallindo, Jakarta

Winda, C. 2009., "Pengenalan Radio Frekuensi Indentification dalam kehidupan seharihari'.Jurnal - Binus University, Jakarta 2009.

Anonim. 2016 .Sistem Palang Pintu Otomatis. https://id.scribd.com/doc/97619011/palangpintu-automatis. Diakses Pada 24 Juli 2016.

Anonim. 2016. Sensor Proximity dan Penjelasan. http://instrumentationelectrical.com/2012/01/proximity-sensor.html. Diakses Pada 22 Juli 2016.

Anonim. 2016.Kamera. Diakses pada 10 Juli 2016.

Anonim. 2016. "Pengertian Motor Servo serta penggunaannya". Diakses pada 15 Juli 2016.

Anonim. 2009. "Electronic and Design" https://books.google.co.id/books?id=DIQvCw AAQBAJ\&pg. Diakses Pada 15 Juli 2016. 